\title{
ECONOMICS AND JUDGING: AN AFTERWORD ON COOTER AND WALD
}

\author{
STEPHEN G. BREYER*
}

I

\section{INTRODUCTION}

The phrase "law and economics"' has both descriptive and prescriptive aspects. Sometimes it is used by those who seek to describe the law by claiming that the common law's major goal is "economic efficiency." Others use it to prescribe, urging judges to create or uphold rules of law which increase wealth, or asking judges to rely more heavily on economics in writing opinions. Professor Cooter's article focuses on the descriptive element; Judge Wald's article focuses on the prescriptive. I shall make a few comments about each and suggest that economics ought to play a real but limited role in judicial decisions. I will begin my comments with an examination of Professor Cooter's arguments. ${ }^{2}$

\section{The Descriptive Element of LaW and Economics}

Since federal law is primarily statutory, federal judges are rarely expert in common law fields; I am no exception, and my comments on Professor Cooter's intelligent, interesting, and provocative paper are, therefore, often tentative or in the form of questions. I make six comments on Professor Cooter's article, and these comments can be divided into two parts: (1) I question whether he has properly captured the notion of liberty, and; (2) as a judicial consumer of these economic principles, I believe he has misapplied them to legal questions.

First, Professor Cooter begins by stating that the reasons judges give for their decisions are complex, and include a desire to achieve such goals as "equity, fairness, efficiency, clarity, [and] administrability."3 Judges are also influenced, according to Professor Cooter, by such factors as "precedent, and

Copyright @ 1988 by Law and Contemporary Problems

- Circuit Judge, United States Court of Appeals for the First Circuit. Note: These comments were made about an early version of Professor Cooter's article given at Duke University in 1986.

1. The law and economics movement is an outgrowth of the writings of many lawyers and economists, including Coase, Calabresi, and Posner. See R. Posner, Economic Analysis of Law (3d ed. 1986); Coase, The Prablem of Social Cost, 3 J.L. \& Econ. 1 (1960).

2. See Cooter, Liberty, Efficiency, and Law, Law \& Contemp. Probs., Autumn 1987, at 141.

3. Id. 
morality, to name a few." 4 I agree, and I am therefore skeptical of any effort to reduce this range of reasons to any single reason concrete enough to be interesting.

Second, the argument that liberty [is] logically more fundamental than wealth $^{5}$ is not convincing. Professor Cooter argues that wealth requires property and that property rights are an aspect of liberty. ${ }^{6}$ Yet, similarly, liberty implies human action, which in turn requires food and clothing, which in turn assumes some form of material wealth. Alternatively, it is not clear that legal property rights are more properly viewed as an aspect of liberty ${ }^{7}$ than as a restraint on liberty; after all, A's right to use a thing implies B's obligation to let A do so.

Third, what is "conjunctive liberty?"8 Professor Cooter says it is the sum of all permitted actions, after each action has been assigned a weight in accordance with its value. ${ }^{9}$ If so, conjunctive liberty is really nothing more than human good, and it is not surprising that law aims at its maximization; so too does every reasonable human institution. One would hope, moreover, that, over time, those rules and precedents which are not conducive to human well-being would gradually disappear from the law. This statement, however, is far too abstract to be of interest.

Fourth, Professor Cooter (and others) often refer to the "purpose" or "goal" of the common law. 10 They cannot mean a legislator's purpose, as there is no legislator of the common law; nor can they mean the judge's purpose, for few, if any, judges consciously or unconsciously try to "maximize wealth" or "maximize liberty" in deciding a typical tort or contract case; nor can they mean the litigants' purposes, for this same reason. Nor is it particularly helpful, for present purposes, to present a metaphor which suggests that a rule-based institution, like the law, is a mythical human being, like Paul Bunyon, who is trying to achieve a single purpose." I suspect that by using the word "purpose" they mean to suggest that, over time, those rules and precedents which do not tend to maximize wealth or liberty disappear from the law, to be replaced by other rules or precedents which tend to achieve these goals. Stated this way, might Professor Cooter's thesis be tested empirically and compared with, say, Judge Posner's? ${ }^{12}$

Fifth, I am not persuaded by Professor Cooter's property examples. For instance, is a damage remedy for an encroaching house more efficient than an injunctive remedy? ${ }^{13}$ Why would the creation of a damage remedy, allowing

4. Id.

5. Id. at $155-56$

6. Id. at 155 .

7. Id.

8. Id. at 149 .

9. See id. at 150 .

10. Id. at $141,156-57,159-62$.

11. Id. at 159-62.

12. See R. Posner, supra note 1. See also Culp, Judex Economicus, Law \& Contemp. Probs., Autumn 1987 , at 95 .

13. See Cooter, original conference manuscript (on file with journal). 
me to enlarge my view by cutting down your tree and paying you damages, "maximize wealth?"14 I do not see how the existence or nonexistence of either remedy would change the use to which the land, house, or tree are put, for, as Professor Coase instructs, ${ }^{15}$ the relevant owners will simply bargain to achieve an efficient result in either case.

Sixth, are there really economists who argue that wealth is maximized through a rule of tort law which seeks to "[f]ind a sum of money such that the parents are indifferent between [(1)] having the money and a dead child or [(2)] not having the money and having their child alive?"16 I think an economist would more likely argue that such a rule does not maximize wealth, but rather leads to enormous damage awards. Victims, of course, want such awards after the accident. Such awards increase insurance premiums, however, and the same victims, viewed as product consumers before the accident, may be unwilling to pay this higher price for a product which they do not yet need. They may prefer to have the product at a lower cost, or to selfinsure, even though fully aware of the possibility that they themselves might turn out to be victims. The damages rule mentioned, insofar as it forces consumers to buy higher-priced insurance than they want, might correspondingly force them to forego products they want more. If so, the rule would be inefficient. Those who call for a greater integration of law and economics would provide a more valuable service by suggesting to those interested in law reform that these arguments at least be considered.

In sum, I am not convinced that Professor Cooter proves that the ultimate purpose of the common law is to "maximize liberty," 17 or that Professor Cooter has completely provided the means whereby judges may pursue such a goal. If, however, he seeks only to show that "maximizing wealth" is not the law's only aim, but that common law rules sometimes encourage commercial transactions, sometimes protect human liberty, and sometimes further other worthwhile objectives, ${ }^{18} \mathrm{I}$ agree. Of this, however, I did not need much convincing.

\section{III}

\section{The Prescriptive Element of Law and Economics}

Judge Wald's article concerns the prescriptive aspect of law and economics, that is, the extent to which the judge should learn economic theory, digest its principles, and reflect them in opinions. She describes her own view of the subject as "pragmatic," placing herself "somewhere between those who would resolve all disputes by economic analysis and those who

14. Id.

15. See Coase, supra note 1. But see Cooter, The Cost of Coase, 11 J. Legal Stud. 1, 24-27 (1982).

16. Cooter, supra note 13.

17. Id.

18. See Culp, Foreword: Economists on the Bench, Law \& ConTemp. Probs., Autumn 1987, at 4. 
would confine the beast to its antitrust and regulatory cage."19 My own views are similar, and some of my reasons closely parallel those of Judge Wald. I would add only the following four comments.

First, economics plays two different kinds of roles in the courtroom. It directly influences the content of the rules of law in antitrust and economic regulation. This fact is not surprising for several reasons: the relevant statutes use terms with economic connotations; ${ }^{20}$ the relevant legislative history is basically consistent with an economic interpretation of the language; such an interpretation furthers important statutory purposes; ${ }^{21}$ and economics provides a desirable certainty of interpretation which alternative bases for interpretation of these statutes typically lack.

Economics also enters the courtroom because practitioners in antitrust and economic regulatory fields must prove specific economic facts related to individual cases; to do so, they must use economic witnesses. This latter relationship of economics to antitrust law is no different in principle from the relationship of medicine to tort law, or that of engineering to contract law.

Outside of antitrust and economic regulation, the importance of economics declines. Of course, the discipline may still provide valuable insights in other areas of the law, for example, when economics experts testify in contract disputes or employment discrimination cases. Yet many other academic disciplines-political theory, statistics, medicine, anthropology, sociology-also provide valuable insights regarding the "proper" shape of the law. The range of different fields from which expert testimony is drawn in typical cases is virtually limitless. ${ }^{22}$

My second comment on Judge Wald's article calls into question the practical value of "economic theory." 23 I become particularly nervous when economic theory begins to inform the interpretation of statutes, largely because most economic theory in this area stems from "interest group theory." Interest group theory suggests that many statutes, particularly

19. Wald, Limits on the Use of Economic Analysis in Judicial Decisionmaking, Law \& Contemp. Probs., Autumn 1987, at 235.

20. See, e.g., Sherman Anti-Trust Act, 15 U.S.C. $\$ 2$ (1982) (using economic terms like "monopolize").

21. See, e.g., R. Bork, The Antrtrust Paradox, 50-71 (1978); but see Kaplow, Antitrust, Law E Economics, and the Courts, LAW \& Contemp. Probs., Autumn 1987, at 206-10.

22. This conclusion reflects, in part, my own experience. I have heard over one thousand cases and written between two hundred and three hundred opinions; yet, I can think of only a handful of cases in which "economic knowledge" seemed particularly useful or relevant. That handful, moreover, with one possible exception, involved antitrust and economic regulation. Indeed, outside of those fields, I should recommend that bench and bar study statistics before they study economics, for with the advent of the discrimination case and the toxic tort case, a knowledge of statistics will likely be indispensable to a judge seeking to evaluate the merits of conflicting evidentiary submissions. (Important mistakes do occur; consider the newspaper articles which recently told us that the odds were billions or trillions to one against a double lottery winner turning up, when, in fact, the odds may have favored the appearance of such a winner. See N.Y. Times, Feb. 27, 1986, at B9, col. 2. Consider, moreover, the relevance of this fact to toxic tort litigation.)

23. See Wald, supra note 19 , at 244. 
regulatory statutes, reflect the views of powerful economic groups. ${ }^{24}$ Interest group theory is interesting, but the more important question is whether it is accurate. In the early 1970's I heard interest group theory used to describe airline regulation in the following manner:

The airlines know the regulatory structure benefits them, while the beneficiaries of deregulation are consumers spread out all over the country. Thus a powerful, organized, knowledgeable interest group opposes an ignorant, disorganized interest group. Obviously, deregulation is impossible. ${ }^{25}$

Yet, the airlines were deregulated, ${ }^{26}$ indicating that some revision of the theory is in order.

In fact, airline regulation provides a good example of the inapplicability of interest group theory. ${ }^{27}$ Regulation gave cartel protection to the airlines, and academics therefore tended to assume (because of Kolko's book on railroad regulation) ${ }^{28}$ that the airlines must have been the ones who sought "cartel protecting" regulation. History reveals, however, that this was not so. The airlines did not believe they were getting price-fixing protection when the regulatory net was passed in $1938 . .^{29}$ One has only to read the historical accounts of the 1938 law $^{30}$ to see how special were the circumstances (involving airline subsidy scandals) leading to its enactment.

The history of airline deregulation suggests that the causes of the early 1970 's regulatory cartel were quite complex. To understand the regulatory problem in the 1960's, one should imagine a highly competitive industry in terms of structure, one involving pricing among 50,000 city pairs in a cyclical industry where cost conditions change rapidly as economic conditions change. How can a regulator ever set prices for such an industry? In fact, the regulators negotiated prices in complicated ways with the industry. The Air Transport Association and the regulators would meet, often informally. Regulation thereby "worked out." It did not leave the consumer too badly off, even though it inhibited price competition.

24. See, e.g., Easterbrook, The Supreme Court, 1983 Term-Foreword: The Court and the Economic System, 98 Harv. L. Rev. 4, $45-58$ (1984). But see Sunstein, Interest Groups in American Public Law, 38 STAN. L. REv. 29 (1985) (Sunstein argues that the interest group hypothesis is historically and morally inappropriate).

25. No one has adopted a version quite as strong as this, but see Posner, Theories of Economic Regulation, 5 Bell J. Econ. \& MGmT. Sc. 335 (1974), and Peltzman, Toward a More General Theory of Regulation, 19 J. L. \& ECON. 211 (1976).

26. See Airline Deregulation Act of 1978, Pub. L. No. 95-504, 92 Stat. 1705 (1978) (codified as amended in scattered sections of 49 U.S.C.).

27. I was general counsel to the Senate Judiciary Committee, Subcommittee on Administrative Practice and Procedure from 1974-1975, and general counsel for the Senate Judiciary Committee from 1979-80. During that service, the Committee considered and passed legislation deregulating the airlines and trucking industries.

28. G. Kulko, Railroads and Regulation, 1877-1916 (1965).

29. Behrman, Civil Aeronautics Board, in The Politics of Regulation 78-86 (W. Jones ed. 1980).

30. See Subcomm. on Administrative Practice and Procedure, Senate Comm. on the Judiciary, 91 st Cong., Ist Sess., Civil Aeronautics Board Practice and Procedures 200-06 (Comm. Print 1975). 
Then, a consumer advocate brought a law suit, Moss v. C.A.B. ${ }^{31}$ The District of Columbia Circuit, viewing the matter as "back-room dealing,"32 held the negotiation illegal. The Civil Aeronautics Board ("CAB") responded with a brilliant procedural idea. It held one very long and complicated set of hearings, out of which emerged a set of rules. The rules were remarkably fair, determining prices everywhere, all at once, and nearly automatically. The rules were perceived as being so fair, in fact, that no lawyer in Washington understood why in 1975 Senator Kennedy wanted to look at the CAB. They thought it an excellent organization because it was a fair organization. Chairman Brown imposed marvelously fair rules, which applied automatically and left nothing about which to argue. The only problem was that the rules also produced price cartelization. The fares were high-too high-and no airline was free to lower its fare. This "perfect cartel," emerging as it did out of a complex set of circumstances, defies explanation through any interest group theory.

Does interest group theory purport to argue that because a group was benefited, that fact alone proves that the group tried to obtain government help and succeeded? If so, one could thereby make the theory true by definition. Yet all political action helps some people and withholds help from others. It is always true that some groups favored the action and others opposed it. If, then, the theory is either factually suspect or fundamentally simplistic, how can judges be expected to use it in interpreting statutes? What, in other words, does interest group theory tell us about what the law ought to be?

Third, efforts to develop "economic formulae" for application in other legal fields too often provide a false sense of accuracy, and, at least sometimes, distract legal attention from more important issues. Consider, for example, the Supreme Court's famous decision in Matthews $v$. Eldridge, ${ }^{33}$ providing a formula for the calculation of the "process" that the fourteenth amendment says is "due." There, courts were instructed to weigh the importance of the private interest that the process is designed to protect (that is, is it a job or welfare benefits?), together with the additional accuracy imported by the (claimed additional) procedure, against the governmental interest in not providing that procedure.

Judge Posner has argued that this formula is an "economic formula," 34 for it weighs the benefit of the added procedure (which weight represents the product of the procedure's importance and its accuracy) against the procedure's cost. Of course, one may wonder whether the only aim of the due process hearing is accuracy in application of a statutory standard. Leaving that point aside, however, one can also wonder about the extent to which the formula helps. That is to say, insofar as one views the formula as an invitation

31. 430 F.2d 891 (D.C. Cir. 1970).

32. Id. at 894 .

33. 424 U.S. 319 (1976).

34. See Sutton v. City of Milwaukee, 672 F.2d 644 (7th Cir. 1982) (Posner, J.). 
to engage in a form of economic cost-benefit analysis, can courts really apply it?

To what extent, for example, can a judge determine the true additional accuracy which more procedures will provide? Will beneficiaries (say, disabled persons) be able to take advantage of the procedures? Will the agency simply enact substantive rules (thereby taking issues away from, say, a hearing examiner), and substitute absolute rule for adjudicatory discretion? Some claim this is what happened in welfare cases. Will procedural formalities have any significant effect on the final substantive decisions? It is argued, for example, that prison discipline more typically involves disputes about how much to punish, not about what actually happened.

Similarly, how accurately can a court gauge the cost to the government of providing additional procedure? Does more procedure mean the government will not try to fire incompetent employees or to remove ineffective drugs from the market place? Does "due process" mean, for the public housing tenant, unremovable, noisy, drug-using neighbors in uninhabitable projects? Does the process expend limited funds and thereby deprive other potential program recipients?

How can courts determine these questions of "cost" or "benefit"? How can they weigh costs and benefits, one against the other? Does an effort to do so distract attention from more workable approaches?

Of course, one might interpret Eldridge as simply directing lower courts to weigh all the relevant factors. This type of instruction is fairly common, and it reflects what courts will do, at least sometimes, even without instruction. Viewed as such, however, Eldridge is not really an invitation to engage in any form of economic analysis.

Fourth, I am now involved in an important test case of the practical value of economic analysis in the criminal law. I am a member of the United States Sentencing Commission, an agency charged by law to fix sentences for all federal crimes within narrow limits, by offense and by type of offender. ${ }^{35}$ The law that created the Commission also abolished parole, ${ }^{36}$ so the sentences that we set will in fact be served. Some members of the Commission believe that sentence type and length should reflect primarily the "just desert" of the convicted defendant. Others believe that it should reflect to a considerable degree the desirability of deterrence as determined by an economic theory of crime. They point to considerable literature discussing the "economic theory,"37 much of which focuses upon sentencing as the instrument of deterrence. Yet, will it prove possible to translate any of this theory into practical rules of decision capable of leading to specific sentence lengths? Are there any empirical studies that will lead, or point the way, to specific sentence

35. See 28 U.S.C. $\$ 994(b)$ (1) (1982).

36. Sentencing Reform Act, 18 U.S.C. $\$ 3551$ (1985).

37. See, e.g., G. Becker \& W. Landes, Essays in the Economics of Crime and Punishment (1974). 
length results? At present, I say only that I do not know. In a few months time, I will, perhaps, have a more informed view.

Although I may have overstated my position, I tend to agree with Judge Wald. I am certain that economic knowledge helps the judge in antitrust and regulatory cases. I am skeptical of, but open to, the possibility that it may be unusually or especially helpful elsewhere. But this special help, except in a very few instances, has yet to be demonstrated. 